Abstract S107 Table 1

\begin{tabular}{llll}
\hline & Control $(\mathbf{n}=\mathbf{5})$ & High-stretch $(\mathbf{n}=\mathbf{3})$ & Atelectasis $(\mathbf{n}=\mathbf{5})$ \\
\hline $\begin{array}{l}\text { Protein in lavage fluid } \\
\text { (mg/ml) }\end{array}$ & $0.21 \pm 0.04$ & $4.07 \pm 2.21^{*}$ & $4.81 \pm 1.67^{*}$ \\
$\begin{array}{l}\text { Perfusate chemokines } \\
\text { MIP-2 (ng/ml) }\end{array}$ & $1.12 \pm 0.70$ & $4.29 \pm 0.82^{*} \dagger$ & $1.48 \pm 0.67$ \\
KC (ng/ml) & $1.26 \pm 0.74$ & $6.71 \pm 1.79^{*} \dagger$ & $1.70 \pm 1.09$ \\
Lavage fluid chemokines & & & \\
MIP-2 (ng/ml) & $0.13 \pm 0.06$ & $4.39 \pm 1.98^{*} \dagger$ & $0.69 \pm 0.26^{*}$ \\
KC (ng/ml) & $0.12 \pm 0.04$ & $5.15 \pm 1.42^{*} \dagger$ & $0.82 \pm 0.47^{*}$ \\
\hline
\end{tabular}

${ }^{*} \mathrm{p}<0.05$ versus control.

$t p<0.05$ versus atelectasis.

MIP-2, Macrophage-inflammatory protein-2; KC, Kerationocyte-derived chemokine.

Conclusion While both high-stretch and atelectasis can induce barrier dysfunction, only high-stretch induced substantial production of chemokines by the lung and their release into the circulation. These findings suggest that over distension of the lung, rather than collapse/reopening associated with atelectasis, primarily contributes to the exacerbated pulmonary and systemic inflammation during VILI. Our results may provide insights into why addition of PEEP to limit atelectasis has limited clinical outcome benefit in ventilated patients with acute lung injury.

\section{Epidemiology of lung disease S108 A HISTORICAL COHORT STUDY TO DETERMINE THE PREVALENCE OF COMMON CHRONIC RESPIRATORY DISEASES AND MEDICATION USE IN DRUG MISUSERS}

doi:10.1136/thx.2010.150946.9

F Palmer, M Jaffray, M Moffat, C Matheson, J Haughney, A Coutts. University of Aberdeen, Aberdeen, Scotland

Introduction and aim A local substance misuse study and anecdotal evidence from primary care, suggested many methadone patients have respiratory disease and/or prescriptions for respiratory preparations. Anecdotal evidence from clinical colleagues supports this. With little published literature in this area, this preliminary study aimed to explore the prevalence of respiratory diseases and prescriptions for respiratory medication in drug misusers.

Method This exploratory study used a historical cohort design with matched controls. An analysis of Primary Care Clinical Informatics Unit (PCCIU) GP consultation data was conducted. The prevalence of common respiratory diseases (ever appearing in the patient's medical records) and commonly used respiratory prescriptions (in 2008) between drug misusers and matched controls (general population sample) was compared.

Results The PCCIU data contained a cohort of 18570 patients (9285 per group), of which, $64 \%(n=11885)$ were male and $75.7 \%$ $(n=14060)$ were aged $31-59$. Results revealed an increased prevalence of chronic respiratory disease in drug misusers versus controls. Drug misusers were more likely to be prescribed chronic respiratory diseases medications than controls. These results were still significant when adjusted for smoking status, where those who had never smoked were compared to those who had ever smoked (current and ex smokers) (See Abstract S108 Table 1). Median quantity of SABA and ICS prescriptions during 2008 were also statistically significantly higher in drug misusers*. The median quantity of SABA prescribed for drug misusers were 4 (IOR 2-8) vs 3 (IOR 1-7) in controls**. The median quantity of ICS prescribed for drug misusers were 4 (IOR 2-8) vs 2 (IOR 1-5) in controls**. *Median Prescription for patients on $\geq 1$ prescription. ${ }^{* *} \mathrm{p}<0.001$ Mann-Whitney U.
Abstract S108 Table 1 Comparisons using PCCIU SPICE data

\begin{tabular}{|c|c|c|c|c|}
\hline & Drug misusers & Controls & $\begin{array}{l}\text { Crude OR } \\
(95 \% \mathrm{Cl})\end{array}$ & $\begin{array}{l}\text { Adjusted OR } \\
\text { (95\% CI) }\end{array}$ \\
\hline Asthma diagnosis & $1590(17.1 \%) \dagger$ & $1009(10.9 \%) \dagger$ & $\begin{array}{l}1.695(1.557 \\
\text { to } 1.845) \neq\end{array}$ & $\begin{array}{l}1.633(1.485 \\
\text { to } 1.796) \ddagger\end{array}$ \\
\hline $\begin{array}{l}\text { COPD (chronic } \\
\text { obstructive } \\
\text { pulmonary disease) } \\
\text { diagnosis }\end{array}$ & $219(2.4 \%) \dagger$ & $74(0.8 \%) \dagger$ & $\begin{array}{l}3.007(2.307 \\
\text { to } 3.920) \neq\end{array}$ & $\begin{array}{l}1.752(1.336 \\
\text { to } 2.297) \neq\end{array}$ \\
\hline $\begin{array}{l}\text { SABA (short acting } \\
\beta \text { agonist) } \\
\text { prescribed* }^{*}\end{array}$ & $1520(16.4 \%) \dagger$ & $736(7.9 \%) \dagger$ & $\begin{array}{l}2.274(2.071 \\
\text { to } 2.496) \neq\end{array}$ & $\begin{array}{l}1.998(1.803 \\
\text { to } 2.214) \neq\end{array}$ \\
\hline $\begin{array}{l}\text { LABA (long acting } \\
\beta \text { agonist) } \\
\text { prescribed }^{*}\end{array}$ & $92(1 \%) \dagger$ & $39(0.4 \%) \dagger$ & $\begin{array}{l}2.373(1.630 \\
\text { to } 3.454) \ddagger\end{array}$ & $\begin{array}{l}1.883(1.255 \\
\text { to } 2.825) \neq\end{array}$ \\
\hline $\begin{array}{l}\text { ICS (inhaled } \\
\text { corticosteroid) } \\
\text { prescribed }^{*}\end{array}$ & $987(10.6 \%) \dagger$ & $702(7.6 \%) \dagger$ & $\begin{array}{l}1.454(1.314 \\
\text { to } 1.609) \ddagger\end{array}$ & $\begin{array}{l}1.500(1.339 \\
\text { to } 1.681) \neq\end{array}$ \\
\hline
\end{tabular}

Conclusion These data suggest, drug misusers have a significantly higher prevalence of respiratory diseases and are prescribed significantly more respiratory medications than matched controls. Adjusting for smoking status, still revealed drug misusers have significantly increased odds of have a respiratory disease or being prescribed respiratory medication, indicating there may be more complex factors involved related to drug use needing further exploration. As a first stage exploratory study, we have set the scene for future work to begin to determine the potential reasons for this association.

\section{S109 CURRENT COPD CARE IN THE UK; RESULTS FROM 180000 PATIENTS IN THE POINTS DATABASE}

doi:10.1136/thx.2010.150946.10

${ }^{1}$ A De Soyza, ${ }^{2} \mathrm{~J}$ Roberts. ${ }^{1}$ Newcastle University /Freeman Hospital, Newcastle upon Tyne, UK; ${ }^{2}$ Salford Royal Hospital NHS Foundation Trust and NHS Salford, Salford, UK

Background COPD is a major healthcare burden in the UK with one million diagnosed patients. Despite a number of evidence-based guidelines, managing COPD is not straightforward. Differing standards of care exist; those qualifying for Quality \& Outcomes Framework QOF versus Non-incentivised NICE guidelines.

Aims To define a large UK wide COPD cohort and describe their current care as recorded in primary care databases.

Methods We interrogated the POINTS ${ }^{1}$ database of all participating practises in the UK. Data were collected between 2007and 2009.

Results 1406 GP Practices participated with total list size $\sim 7.9$ million of these $\sim 180000$ COPD patients were listed. 1009 practices returned list sizes giving approximately $1.8 \%$ prevalence of COPD. Approx 45000 (25\%) were current smokers of these 31000 (69\% of smokers) had received recent smoking cessation education $30 \%$ were of working age ( $<65$ years). $96000(50 \%)$ had a FEV 1 recorded within 12 months, 147000 had flu and/or pneumococcal vaccination status recorded (80\%). Only 15\% (27500) had exacerbation frequency recorded. Progressive increases in MRC dyspnoea score (MRCD) recording occurred each year from 2007 at $29 \%$ to $44 \%$ in 2009. The most common prescription was short acting $\beta$ agonist SABA in $66 \%$, Inhaled corticosteroid/Long acting $\beta$ agonist (ICS/LABA) combination inhaler in $47 \%$, LAMA (long acting muscarinic antagonist) in 30\%. We noted $27514(15 \%)$ were prescribed an ICS inhaler which is out of licence and against NICE guidelines. $6 \%$ were prescribed a mucolytic.

Conclusions This cohort is one of the largest reported. Certain limitations may apply: possible non-random participation of practises, incorrect COPD diagnosis and incomplete datasets. Despite exacerbation rate reduction being a key management goal, 